\title{
Effect of Chronic Cadmium Exposure on Antioxidant Defense System in Some Tissues of Rats: Protective Effect of Selenium
}

\author{
B. I. OGNJANOVIĆ, S. D. MARKOVIĆ, S. Z. PAVLOVIĆ ${ }^{1}$, R. V. ŽIKIĆ, A. Š. ŠTAJN, \\ Z. S. SAIČIĆ ${ }^{1}$
}

Institute of Biology and Ecology, Faculty of Science, University of Kragujevac, Kragujevac,

${ }^{1}$ Institute for Biological Research "Siniša Stanković", Department of Physiology, Belgrade, Serbia

Received January 17, 2007

Accepted March 20, 2007

On-line May 30, 2007

\section{Summary}

The effects of selenium (Se) on antioxidant defense system in liver and kidneys of rats with cadmium (Cd)-induced toxicity were examined. Cd exposure (15 mg Cd/kg b.m./day as $\mathrm{CdCl}_{2}$ for 4 weeks) resulted in increased lipid peroxidation (LP) in both organs $(p<0.005$ and $p<0.01)$. Vitamin $C($ Vit $C)$ was decreased in the liver $(p<0.005)$, whereas vitamin $E$ (Vit $E)$ was increased in the liver and kidneys $(p<0.005$ and $p<0.05)$ of $C d$-exposed animals. Superoxide dismutase (SOD) and glutathione peroxidase (GSH-Px) activities were decreased in both tissues $(p<0.05$ and $p<0.005$ ), whereas catalase (CAT) activity was decreased only in liver $(p<0.005)$. Glutathione S-transferase (GST) increased in both tissues $(p<0.005$ and $p<0.01)$. Treatment with Se $(0.5 \mathrm{mg}$ $\mathrm{Se} / \mathrm{kg}$ b.m./day as $\mathrm{Na}_{2} \mathrm{SeO}_{3}$ for 4 weeks) significantly increased liver and kidneys SOD and GSH-Px activities ( $p<0.05$ to $\mathrm{p}<0.005$ ), as well as CAT and GST activities only in the liver $(p<0.01)$. In animals exposed to Se, both the concentrations of Vit $C(p<0.01)$ and Vit $E(p<0.005)$ were increased in both tissues. Co-treatment with Se resulted in reversal of oxidative stress with significant decline in analyzed tissues $\mathrm{Cd}$ burden. Our results show that Se may ameliorate Cd-induced oxidative stress by decreasing LP and altering antioxidant defense system in rat liver and kidneys and that Se demonstrates the protective effect from cadmium-induced oxidative damage.

\section{Key words}

Antioxidant defense system • Cadmium • Lipid peroxides • Selenium • Rat

\section{Corresponding author}

Branka I. Ognjanović, Institute of Biology and Ecology, Faculty of Science, University of Kragujevac, Radoja Domanovića 12, P.O. Box 60, 34000 Kragujevac, Serbia. Fax: (+381) 34335 040, E-mail: branka@kg.ac.yu

\section{Introduction}

Cadmium (Cd) is an industrial and environmental pollutant, arising primarily from battery, electroplating, pigment, plastic, fertilizer industries, and cigarette smoke. $\mathrm{Cd}$ is dangerous because humans consume both plants and animals that absorb $\mathrm{Cd}$ efficiently and concentrate it within their tissues (Stohs and Bagchi 1995). Cd shows various mechanisms of toxicity in particular species under different experimental conditions (Iscan et al. 1994, Žikić et al. 1996, Waisberg et al. 2003). It has been demonstrated that $\mathrm{Cd}$ stimulates free radical production, resulting in oxidative deterioration of lipids, proteins and DNA, and initiating various pathological conditions in humans and animals (Waisberg et al. 2003). Once absorbed, Cd is rapidly cleared from the blood and concentrates in various tissues. Chronic exposure to inorganic $\mathrm{Cd}$ results in accumulation of the metal mainly in the liver and kidneys, as well as in other tissues and organs causing many metabolic and histological changes, membrane damage, altered gene expression and apoptosis (Shaikh et al. 1999, Casalino et al. 2002, Waisberg et al. 2003).

Among antioxidant micronutrients, selenium (Se) is an essential dietary trace element, which plays an important role in a number of biological processes in humans and other species. Deficiency of this element induces some pathological conditions, such as cancer, coronary heart disease, and liver necrosis (Saito et al. 2003, Wu and Huang 2004, Agay et al. 2005). Se taken in the form of selenite, selenate, selenocysteine, and 
selenomethionine is most absorbed in the duodenum. After the absorption, increased levels of Se have been detected in the blood plasma proteins and from there it can be distributed into the tissues where it is incorporated in newly synthesized seleno-proteins. Considerable $\mathrm{Se}$ uptake by erythrocytes was described by Combs and Gray (1998).

Se is an essential component of several enzymes such as glutathione peroxidase (GSH-Px), thioredoxin reductase (TR) and selenoprotein $\mathrm{P}(\mathrm{SeP})$, which contain $\mathrm{Se}$ as selenocysteine. It is also well known that $\mathrm{Se}$ is essential for cell culture when a serum-free medium is used (Kim and Combs 1993, Saito et al. 2003). It is also known, that Se has a certain protective role from the toxic actions of $\mathrm{Cd}$ and other heavy metals (Jamall and Sprowls 1987, Ognjanović et al. 1995, Žikić et al. 1998). This protection includes the capability of Se to alter the distribution of $\mathrm{Cd}$ in tissues and induces binding of the Cd-Se complexes to proteins, which are similar to metallothioneins (Jamba et al. 1997, Combs and Gray 1998).

In the present experiments, the influence of $\mathrm{Cd}$ and $\mathrm{Se}$ on the antioxidant defense system (AOS), as well as on LP, $\mathrm{Cd}$ and $\mathrm{Se}$ concentrations in the liver and kidneys of rats were analyzed. After 30 days of exposure, the activities of enzymatic (SOD, CAT, GSH-Px and GST) and non-enzymatic (Vit C and Vit E) components of this system were determined. The possible protective role of Se against the toxic effects of $\mathrm{Cd}$ has been especially considered.

\section{Methods}

Wistar male 60-day-old rats (weighing $200 \pm$ $20 \mathrm{~g}$ ) were used. The animals were kept at $21 \pm 2{ }^{\circ} \mathrm{C}$, fed with pellet rat diet, and exposed to $12 \mathrm{~h}$ light $/ 12 \mathrm{~h}$ dark cycle. Group 1 was used as controls. The rats of the experimental groups were exposed to: Group 2 to cadmium $\left(15 \mathrm{mg} \mathrm{Cd} / \mathrm{kg}\right.$ body mass/day as $\mathrm{CdCl}_{2}$ for 4 weeks), Group 3 to selenium $(0.5 \mathrm{mg} \mathrm{Se} / \mathrm{kg}$ body mass/day as $\mathrm{Na}_{2} \mathrm{SeO}_{3}$ for 4 weeks) and Group $4 \mathrm{Cd}+\mathrm{Se}$ in above mentioned amounts. Every group consisted of 8 animals. All chemicals were from Sigma (St. Louis, MO, USA).

All rats of each group were killed at the end of the treatment period. Liver and kidneys were minced and homogenized $(10 \%, w / v)$ separately in ice-cold saline, sucrose buffer $(0.25 \mathrm{M}$ sucrose, $1 \mathrm{mM}$ EDTA and $0.05 \mathrm{M}$ Tris-HCl, $\mathrm{pH}$ 7.4) in a Thomas Sci Co. glass-type homogenizer (Teflon pestle). Tissues homogenate from both control and treated rats were used for Vit $\mathrm{C}$ and Vit $\mathrm{E}$ determination. The homogenate was centrifuged at $100000 \times g$ for $90 \mathrm{~min}$ at $4{ }^{\circ} \mathrm{C}$ and the supernatant was used for antioxidant enzyme assays.

Concentration of $\mathrm{Cd}$ in the liver and kidneys was determined by atomic absorption spectrophotometry using a Perkin-Elmer Model 5000 (Shirley et al. 1949), while the concentration of $\mathrm{Se}$ was determined by fluorimetric method (Dye et al. 1960).

The concentration of LP measured as thiobarbituric acid reactive substances (TBARS) in the tissues of rat was assayed by the method of Ohkawa et al. (1979).

Superoxide dismutase (SOD) activity was determined by the epinephrine method (Misra and Fridovich 1972). Catalase (CAT) activity was measured by the method of Beutler (1982). The activity of glutathione peroxidase (GSH-Px) was assayed by following the oxidation of NADPH at $340 \mathrm{~nm}$ with t-butyl-hydroperoxide (Tamura et al. 1982). Glutathione S-transferase (GST) activity toward 1-chloro-2,4dinitrobenzene as a substrate was determined according to Habig et al. (1974). All enzyme activities were expressed per $g$ of wet tissue ( $\mathrm{U} / \mathrm{g}$ tissue).

Vitamin C concentration was determined spectrophotometrically by dinitrophenyl-hydrazine method at $530 \mathrm{~nm}$ (Omaye et al. 1979). Vitamin E was measured by the method of Desai (1984) based on the reduction of $\mathrm{Fe}^{3+}$ in $\mathrm{Fe}^{2+}$ in the presence of tocopherol and production of colored complex with bathophenanthroline.

The data were expressed as the mean \pm S.E.M. and were analyzed by means of one-way analysis of variance (ANOVA). Statistical evaluation of data was done following Student's $t$-test. A difference was considered significant at $p<0.05$.

\section{Results}

The concentrations of $\mathrm{Cd}$ in the liver and kidneys were significantly increased in animals exposed to $\mathrm{Cd}$ and in animals exposed to $\mathrm{Cd}$ and $\mathrm{Se}$ concomitantly $(p<0.005)$. Concentration of Se was increased $(p<0.005)$ after exposure to Se only and after to concomitant exposure both to $\mathrm{Cd}$ and $\mathrm{Se}(\mathrm{p}<0.005$ and $\mathrm{p}<0.01)$ (Table 1).

Results indicated that LP concentration was significantly increased in the liver $(\mathrm{p}<0.005)$ and kidneys 
Table 1. Cadmium (Cd) and selenium (Se) concentrations in liver and kidneys of controls and rats treated with cadmium (Cd), selenium (Se) or their combination (Cd+Se).

\begin{tabular}{lcccc}
\hline & \multicolumn{4}{c}{ Experimental groups } \\
\cline { 2 - 5 } & Control & Cd & Se & Cd+Se \\
\hline Cd $(\mu g / g$ tissue $)$ & & & \\
Liver & $0.32 \pm 0.01$ & $21.26 \pm 1.72^{* * *}$ & $0.24 \pm 0.02$ & $24.53 \pm 1.12^{* * *}$ \\
Kidneys & $0.42 \pm 0.01$ & $23.44 \pm 1.68^{* * *}$ & $0.47 \pm 0.03$ & $23.25 \pm 1.31^{* * *}$ \\
\hline Se $(\mu g / g$ tissue $)$ & & & & \\
Liver & $0.72 \pm 0.04$ & $0.64 \pm 0.08$ & $1.83 \pm 0.09^{* * *}$ & $1.43 \pm 0.05^{* * *}$ \\
Kidneys & $0.52 \pm 0.02$ & $0.25 \pm 0.02^{* *}$ & $1.28 \pm 0.06^{* * *}$ & $0.75 \pm 0.06^{* *}$ \\
\hline
\end{tabular}

Data are expressed as mean \pm S.E.M. $n=8$ for each groups. Significantly different from controls: $* p<0.05, * * p<0.01, * * * p<0.005$.

Table 2. Concentration of lipid peroxides ( $L P, n m o l / g$ tissue) in liver and kidneys of controls and rats treated with cadmium (Cd), selenium (Se) or their combination (Cd+Se).

\begin{tabular}{lcccc}
\hline & \multicolumn{4}{c}{ Experimental groups } \\
\cline { 2 - 5 } & Control & Cd & Se & Cd + Se \\
\hline Liver & $27.43 \pm 2.64$ & $42.61 \pm 3.84^{* * *}$ & $24.36 \pm 2.17$ & $29.82 \pm 2.72$ \\
Kidneys & $20.56 \pm 1.18$ & $27.63 \pm 1.75^{* *}$ & $16.38 \pm 0.64^{*}$ & $23.15 \pm 1.26$ \\
\hline
\end{tabular}

Data are expressed as mean \pm S.E.M. $\mathrm{n}=8$ for each groups. Significantly different from controls: $* \mathrm{p}<0.05, * * p<0.01, * * * p<0.005$.

Table 3. Vitamin C (Vit C) and vitamin E (Vit E) concentrations in liver and kidneys of controls and rats treated with cadmium (Cd), selenium (Se) or their combination (Cd+Se).

\begin{tabular}{|c|c|c|c|c|}
\hline & \multicolumn{4}{|c|}{ Experimental groups } \\
\hline & Control & Cd & Se & $\mathbf{C d}+\mathbf{S e}$ \\
\hline \multicolumn{5}{|c|}{ Vit $C(m g \%)$} \\
\hline Liver & $37.60 \pm 0.84$ & $30.01 \pm 0.39^{* * *}$ & $45.23 \pm 1.58^{* *}$ & $34.53 \pm 0.61$ \\
\hline Kidneys & $21.90 \pm 0.53$ & $20.87 \pm 0.91$ & $25.84 \pm 1.71^{* *}$ & $23.68 \pm 1.23$ \\
\hline \multicolumn{5}{|c|}{ Vit $E(\mu g / g$ tissue $)$} \\
\hline Liver & $13.41 \pm 0.69$ & $23.32 \pm 0.65^{* * *}$ & $26.97 \pm 1.50^{* * *}$ & $16.04 \pm 0.48$ \\
\hline Kidneys & $15.73 \pm 0.87$ & $17.96 \pm 0.53^{*}$ & $27.01 \pm 1.46^{* * *}$ & $15.82 \pm 0.80$ \\
\hline
\end{tabular}

Data are expressed as mean \pm S.E.M. $\mathrm{n}=8$ for each groups. Significantly different from controls: $* \mathrm{p}<0.05, * * \mathrm{p}<0.01, * * * \mathrm{p}<0.005$.

$(p<0.01)$ of rats treated with $\mathrm{Cd}$. Co-treatment with Se was very effective in the prevention of oxidative damage induced by $\mathrm{Cd}$, which resulted in significantly lower LP concentration (Table 2).

Figures 1 and 2 show significant changes in the activity of AOS enzymes during the treatment of rats with $\mathrm{Cd}$, Se and their combination. SOD and GSH-Px activities were significantly decreased $(p<0.05$ and $\mathrm{p}<0.005$ ) in the liver (Fig. 1) and kidneys (Fig. 2), whereas CAT activity was decreased $(\mathrm{p}<0.005)$ only in the liver (Fig. 1) of the animals exposed to $\mathrm{Cd}$. Treatment with $\mathrm{Cd}$ significantly increased liver $(\mathrm{p}<0.005)$ and kidneys ( $<<0.01)$ GST activity (Figs 1 and 2 ). Treatment with Se alone significantly increased liver and kidneys SOD $(p<0.01$ and $p<0.005)$ and GSH-Px $(p<0.01$ and $\mathrm{p}<0.05$ ) activities as well as CAT and GST activities only 

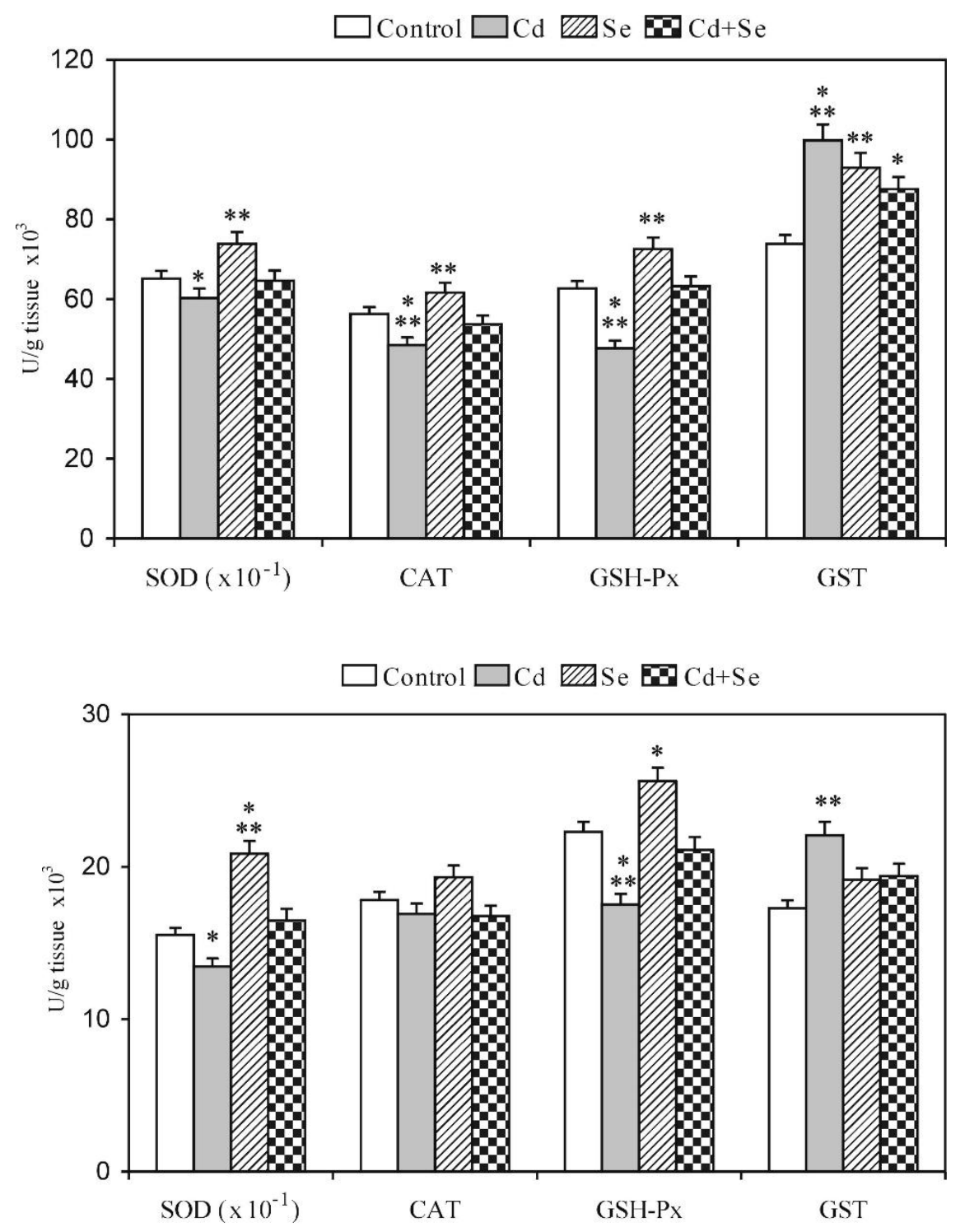

Fig. 1. The activity of antioxidant enzymes (SOD, CAT, GSH-Px and GST) in liver of controls and rats treated with cadmium (Cd), selenium (Se) or their combination $(\mathrm{Cd}+\mathrm{Se})$. Data are expressed as mean \pm S.E.M. $\mathrm{n}=8$ for each groups. Significantly different from controls: $* \mathrm{p}<0.05, * * \quad \mathrm{p}<0.01$, $* * * \mathrm{p}<0.005$.
Fig. 2. The activity of antioxidant enzymes (SOD, CAT, GSH-Px and GST) in kidneys of controls and rats treated with cadmium (Cd), selenium (Se) or their combination $(\mathrm{Cd}+\mathrm{Se})$. Data are expressed as mean \pm S.E.M. $n=8$ for each groups. Significantly different from controls: $* \mathrm{p}<0.05, \quad * * \quad \mathrm{p}<0.01$, $* * * \mathrm{p}<0.005$. in liver $(\mathrm{p}<0.01)$. Administration of $\mathrm{Cd}$ with Se did not cause significant changes in activity of this enzyme in comparison with control group, while alleviated the harmful effects of $\mathrm{Cd}$ (Figs 1 and 2).

Table 3 shows the concentrations of Vit $\mathrm{C}$ and $\mathrm{Vit} \mathrm{E}$ in the liver and kidneys. Exposure to $\mathrm{Cd}$ caused significant decrease of Vit $\mathrm{C}$ in the liver $(\mathrm{p}<0.005)$ and concomitant increase of Vit $E$ in liver $(p<0.005)$ and kidneys $(p<0.05)$ of rats. In animals exposed to Se both the concentrations of Vit $\mathrm{C}(\mathrm{p}<0.01)$ and Vit $\mathrm{E}(\mathrm{p}<0.005)$ were increased. Concomitant treatment with $\mathrm{Cd}$ and $\mathrm{Se}$ did not cause significant changes in concentration of this vitamin in both the tissues compared to control group.

\section{Discussion}

$\mathrm{Cd}$ has been recognized as one of the most toxic environmental and industrial pollutants. $\mathrm{Cd}$ is an ubiquitous toxic metal that may induce oxidative damage by disturbing the prooxidant-antioxidant balance in the tissues. A significantly increased accumulation of $\mathrm{Cd}$ in liver and kidneys were observed in animals treated with Cd (Table 1). Liver, kidney, lung, testes, and heart are the target organs following $\mathrm{Cd}$ exposure, with the severity of their intoxication dependent on the route, dose, and duration of the exposure to the metal (Ognjanović et al. 1995, Casalino et al. 1997, Štajn et al. 1997). In the cell, Cd mainly accumulates in the cytosol $(70 \%)$, followed by the nucleus (15\%) and lowest in mitochondria and the endoplasmic reticulum (Casalino et al. 1997).

Previous investigations show that peroral intake of $\mathrm{Cd}$ induces its accumulation in the red blood cells (Kostić et al. 1993), the heart (Žikić et al. 1998) and the skeletal muscle of rats (Pavlović et al. 2001), which was accompanied by considerable alterations of enzymatic and non-enzymatic component of AOS. With increasing 
Cd concentration in the liver and kidneys, Se concentration also rises, although it was not administered additionally (Table 1). The increased Se concentration in the liver and kidneys could be explained by its redistribution from other tissues and organs (Jamall and Smith 1985) as well as by forming of Cd-Se protein complexes (Jamba et al. 1997, Combs and Gray 1998). The accumulation of both elements increased in liver and kidneys after concomitant exposure of rats to both $\mathrm{Cd}$ and Se. All these data indicate that Se diminished the toxic effects of $\mathrm{Cd}$ and increased the accumulation of $\mathrm{Cd}$ in liver and kidneys (Wahba et al. 1993).

Lipid peroxidation is one of the main manifestations of oxidative damage, which plays an important role in the toxicity of many xenobiotics (Stohs and Bagchi 1995, Anane and Creppy 2001). Our data (Table 2) confirm that chronic intoxication with cadmium causes a significant increase of LP concentration in liver and kidneys of rats. Since it causes lipid peroxidation in numerous tissues both in vivo and in vitro (Kostić et al. 1993, Sarkar et al. 1998, Ognjanović et al. 2003, ElDemerdash et al. 2004), it has been suggested that $\mathrm{Cd}$ may induce oxidative stress by producing hydroxyl radicals (O'Brien and Salasinski 1998), superoxide anions, nitric oxide and hydrogen peroxide (Koizumi et al. 1996, Waisberg et al. 2003). Moreover, it has been shown that various antioxidants and antioxidant defense systems protect cells from Cd-induced toxicity (Shaikh et al. 1999, Tandon et al. 2003, Ognjanović et al. 2006).

Co-treatment with Se was very effective in the prevention of oxidative damage induced by $\mathrm{Cd}$, which resulted in significantly lower LP concentration in the liver and kidneys (Table 2). This can be explained by the important role of Se in preventing lipid peroxidation and in protection of integrity and functioning of tissues and cells.

The prevention of lipid peroxidation is essential for all aerobic organisms and so the organism is well equipped with antioxidants that directly or indirectly protect cells against the adverse effects of xenobiotics, carcinogens and toxic radicals (Halliwell and Gutteridge 1999). The role of antioxidants in reversing this oxidative stress has been of long-standing interest to basic scientists and clinicians (Matés 2000).

Figures 1 and 2 show significant changes in the activity of AOS enzymes during the treatment of rats with $\mathrm{Cd}$ and Se. SOD and GSH-Px activities were decreased in liver (Fig. 1) and kidneys (Fig. 2), whereas CAT activity was decreased only in the liver (Fig. 1). This is probably a consequence of the intracellular accumulation of ROS with subsequent development of liver and kidney injury. Accumulation of $\mathrm{Cd}$ and SOD inhibition was highest in liver followed by kidneys, indicating a direct effect of $\mathrm{Cd}$ on SOD activity. This suggests a role of free radicals in causing cellular damage during long-term exposure to $\mathrm{Cd}$ (Patra et al. 1999). The decreased activity of GSH-Px can be explained by competition of Cd-metallothioneins and GSH-Px for sulfur containing aminoacids (Waisberg et al. 2003). Studies of other authors have shown that $\mathrm{Cd}$ inhibits the activity of majority of enzymes involved in AOS (Jamall and Sprowls 1987, Sarkar et al. 1998, Casalino et al. 2002) inducing an increased production of free radicals, lipid peroxidation, and destruction of cell membranes (Kostić et al. 1993, Casalino et al. 1997, Ognjanović et al. 2003). Cd also inhibits the activities of many enzymes by binding to their sulfhydryl groups or by inhibiting the protein synthesis (Shaikh et al. 1999, Waisberg et al. 2003).

The increased activity of GST in liver and kidneys (Figs 1 and 2) is in agreement with our previous findings that the exposure to $\mathrm{Cd}$ causes an increased activity of GST in the plasma, heart and skeletal muscle (Kostić et al. 1993, Pavlović et al. 2001, Ognjanović et al. 2003, 2006). Other authors showed that $\mathrm{Cd}$ exposure increased the activity of this enzyme in different tissues. Indeed, an increased hepatic GST activity in rat (Casalino et al. 2004) and guinea pig (Iscan et al. 1994) has been observed. The GST enzyme has an important role in detoxification of xenobiotics, drugs and carcinogens and thus protects the cells against redox cycling and oxidative stress (Matés 2000, Casalino et al. 2004).

Treatment with Se alone significantly increased liver and kidneys SOD and GSH-Px activities, as well as CAT and GST activities in the liver only. By concomitant exposure of rats both to $\mathrm{Cd}$ and $\mathrm{Se}$, the activities of SOD, CAT and GSH-Px remain at the level of the control values, indicating that Se eliminates the toxic effects of $\mathrm{Cd}$ on the activity of these enzymes. However, the activity of GST in the liver of these animals was increased. In rats exposed to $\mathrm{Cd}$ and Se separately, this can be explained by an important role played by this enzyme in preventing lipid peroxidation and oxidative damage of the liver (Jamall and Smith 1985, Kim and Combs 1993).

The antioxidants such as Vit E, Vit $\mathrm{C}$ and GSH protect the erythrocyte membrane from oxidative damage (Beyer 1994, Griffith 1999, Ognjanović et al. 2003). Shaikh et al. (1999) concluded that oxidative stress 
appears to play a major role in chronic $\mathrm{Cd}$-induced hepatic and renal toxicity since the inhibition of components of the antioxidant defense system enhanced and the administration of Vit $\mathrm{E}$ protected against $\mathrm{Cd}$ toxicity. Carotenoids can also function directly as antioxidants by reacting with active oxygen species (ElDemerdash et al. 2004). In the present study, Se reduced cellular toxicity caused by Cd-induced ROS and protected the liver (Fig. 1) and kidney (Fig. 2) antioxidant system. The effects of Se may be related either to the formation of $\mathrm{Cd}-\mathrm{Se}$ complexes in association with metallothioneins, or to the changes in tissue $\mathrm{Cd}$ distribution (Viljoen and Tappel 1988, Jamba et al. 1997).

Our data (Table 3) show that Cd significantly decreases Vit $\mathrm{C}$ concentration in the rat liver, which is in accordance with other reports (Chatterjee et al. 1973, Shukla and Chandra 1989). It is known that increased accumulation of $\mathrm{Cd}$ in the liver induces lipid peroxidation and increases the production of malondialdehyde (MDA) (Tandon et al. 2003), which consequently inhibits the enzyme L-gulonolactone oxidase (Chatterjee et al. 1973, Hudecová and Ginter 1992) that is necessary for synthesis of Vit $\mathrm{C}$, which is a potent scavenger of free oxygen radicals. Its deficiency results in intracellular oxidative damage in the guinea-pig (Nagyova et al. 1994). In rats exposed to increased concentrations of Se, an opposite effect was observed (Table 3), because the concentrations of Vit $\mathrm{C}$ in liver and kidneys were significantly increased. From our results it can be concluded that the inhibitory effect of $\mathrm{Cd}$ on the concentration of Vit $\mathrm{C}$ is more pronounced than the stimulatory effects of Se, since the concentration of Vit $\mathrm{C}$ in the liver was significantly lower in rats concomitantly exposed to both $\mathrm{Cd}$ and $\mathrm{Se}$ than in control animals. Both $\mathrm{Cd}$ and Se significantly increase Vit $\mathrm{E}$ concentration in rat liver and kidney (Table 3 ). Vit $\mathrm{E}$ is a major free radical chain-breaking antioxidant, that can also interfere with the initiation and progression of $\mathrm{Cd}$-induced oxidative damage. As a primary liposoluble antioxidant, it has an important role in scavenging of free oxygen radicals and stabilizing the cell membranes, thus maintaining their permeability (Beyer 1994). Moreover, it is known that antioxidants, such as Vit E, coenzyme Q, Vit C, beta-carotene, GSH and Se, may act synergically, preventing lipid peroxidation and cell destruction (Griffith 1999, Navarro et al. 1999, El-Demerdash et al. 2004). It is well known that $\mathrm{Se}$ and Vit $\mathrm{E}$ show compensative effects and that a deficiency of both elements may cause massive injury (Saito et al. 2003).

Our previous investigations showed that chronic treatment with $\mathrm{Cd}$ induces a decrease of Vit $\mathrm{C}$ concentration in plasma, the liver (Žikić et al. 1995) and kidneys (Štajn et al. 1997) of young and adult rats, while $\mathrm{Cd}$ increases the concentration of Vit $\mathrm{E}$ in the rat heart (Ognjanović et al. 2006), kidneys (Štajn et al. 1997) and plasma (Kostić et al. 1993, Ognjanović et al. 2003). Thus, a number of studies have been carried out to determine the protective effects of $\mathrm{Se}$ in different biological models of injury (Kim and Combs 1993, Combs and Gray 1998, Agay et al. 2005).

It can be concluded from the present study that $\mathrm{Cd}$ accumulation in liver and kidneys of rats, due to chronic dietary intake of $\mathrm{Cd}$, is associated with marked alterations of enzymatic (SOD, CAT, GSH-Px and GST) and nonenzymatic components (Vit C and Vit E) of AOS. Data suggest that lipid peroxidation was associated with $\mathrm{Cd}$ toxicity in both tissues. Our results showed that the nutritional antioxidant Se ameliorated oxidative stress and loss of cellular antioxidants and suggested that Se efficiently protect liver and kidneys from $\mathrm{Cd}$-induced oxidative damage. This protection includes the capability of $\mathrm{Se}$ to alter the distribution of $\mathrm{Cd}$ in tissues and to induce binding of the $\mathrm{Cd}-\mathrm{Se}$ complexes to proteins, which are similar to metallothioneins.

\section{Conflict of Interest}

There is no conflict of interest.

\section{Acknowledgements}

This work was supported by the Ministry of Science of Republic of Serbia, Grant No. 143035B.

\section{References}

AGAY D, SANDRE C, DUCROS V, FAURE H, CRUZ C, ALONSO A, ROUSSEL AM, CHANCERELLE Y: Optimization of selenium status by a single intraperitoneal injection of Se in Se-deficient rat: possible application to burned patient treatment. Free Radic Biol Med 39: 762-768, 2005.

ANANE R, CREPPY EE: Lipid peroxidation as pathway of aluminium cytotoxicity in human skin fibroblast cultures: prevention by superoxide dismutase and catalase and vitamins E and C. Hum Exp Toxicol 20: 477-481, 2001. 
BEUTLER E: Catalase. In: Red Cell Metabolism, a Manual of Biochemical Methods. E BEUTLER (eds), Grune and Stratton, New York, 1982, pp 105-106.

BEYER RE: The role of ascorbate in antioxidant protection of biomolecules: interaction with vitamin $\mathrm{E}$ and coenzyme Q. J Bioenerg Biomemb 26: 349-358, 1994.

CASALINO E, SBLANO C, LANDRISCINA C: Enzyme activity alteration by cadmium administration to rats: the possibility of iron involvement. Arch Biochem Biophys 346: 171-179, 1997.

CASALINO E, CALZARETTI G, SBLANO C, LANDRISCINA C: Molecular inhibitory mechanisms of antioxidant enzymes in rat liver and kidney by cadmium. Toxicology 179: 37-50, 2002.

CASALINO E, SBLANO C, LANDRISCINA V, CALZARETTI G, LANDRISCINA C: Rat liver glutathione Stransferase activity stimulation following acute cadmium or manganese intoxication. Toxicology 200: 29-38, 2004.

CHATTERJEE GC, BANERJEE SK, PAL RD: Cadmium administration and L-ascorbic acid metabolism in rats. Effects of L-ascorbic acid supplementation. Int J Vitam Nutr Res 43: 370-377, 1973.

COMBS G, GRAY WP: Chemopreventive agents: selenium. Pharmacol Ther 79: 179-192, 1998.

DESAI ID: Vitamin E analysis methods for animal tissues. Methods Enzymol 105: 138-147, 1984.

DYE WB, BRETHAWER E, SEIM HJ, BLINCOE C: Fluorimetric determination of selenium in plants and animal with 3,3'-diaminobenzidine. Anal Chem 35: 1687-1693, 1960.

EL-DEMERDASH FM, YOUSEF MI, KEDWANY FS, BAGHDADI HH: Cadmium-induced changes in lipid peroxidation, blood hematology, biochemical parameters and semen quality of male rats: protective role of vitamin E and beta-carotene. Food Chem Toxicol 42: 1563-1571, 2004.

GRIFFITH OW: Biological and pharmacologic regulation of mammalian glutathione synthesis. Free Radic Biol Med 27: 922-935, 1999.

HABIG WH, PABST MJ, JAKOBY WB: Glutathione-S-transferase. J Biol Chem 249: 7130-7139, 1974.

HALLIWELL B, GUTTERIDGE JMC: Free Radicals in Biology and Medicine, Third edition, Oxford University Press, New York, 1999.

HUDECOVA A, GINTER E: The influence of ascorbic acid on lipid peroxidation in guinea pigs intoxicated with cadmium. Food Chem Toxicol 30: 1011-1013, 1992.

ISCAN M, COBAN T, EKE BC: Differential combined effect of cadmium and nickel on hepatic and renal glutathione S-transferase of the guinea pig. Environ Health Perspect 102: 69-72, 1994.

JAMBA L, NEHRU B, BANSAL MP: Redox modulation of selenium binding proteins by cadmium exposures in mice. Mol Cell Biochem 177: 169-175, 1997.

JAMALL IS, SMITH JC: The effects of dietary selenium on cadmium binding in rat kidney and liver. Arch Toxicol 56: 252-255, 1985.

JAMALL IS, SPROWLS JJ: Effects of cadmium and dietary selenium on cytoplasmic and mitochondrial antioxidant defense systems in the heart of rats fed high dietary copper. Toxicol Appl Pharmacol 87: 102-110, 1987.

KIM YS, COMBS JGF: Effects of dietary selenium and vitamin E on glutathione concentrations and glutathione S-transferase activities in chick liver and plasma. Nutr Res 13: 455-463, 1993.

KOIZUMI T, SHIRAKURA G, KUMAGAI H, TATSUMOTO H, SUZUKI KT: Mechanism of cadmium-induced cytotoxicity in rat hepatocytes: cadmium-induced active oxygen-related permeability changes of the plasma membrane. Toxicology 114: 124-134, 1996.

KOSTIĆ MM, OGNJANOVIĆ B, DIMITRIJEVIĆ S, ŽIKIĆ RV, ŠTAJN A, ROSIĆ GL: Cadmium-induced changes of antioxidant and metabolic status in red blood cells of rats: in vivo effects. Eur J Haematol 51: 86-92, 1993.

MATÉS M: Effects of antioxidant enzymes in the molecular control of reactive oxygen species toxicology. Toxicology 153: 83-104, 2000.

MISRA HP, FRIDOVICH I: The role of superoxide anion in the autooxidation of epinephrine and simple assay for superoxide dismutase. J Biol Chem 247: 3170-3175, 1972.

NAGYOVA A, GALBAVY S, GINTER E: Histopathological evidence of vitamin C protection against Cdnephrotoxicity in guinea pigs. Exp Toxicol Pathol 46: 11-14, 1994. 
NAVARRO F, ARROYO A, MARTIN SF, BELLO RI, DE CABO R, BURGESS JR, NAVAS P, VILLALBA JM: Protective role of ubiquinone in vitamin E and selenium-deficient plasma membranes. BioFactors 9: 163-170, 1999.

O'BRIEN P, SALASINSKI HJ: Evidence that the reactions of cadmium in the presence of metallothionein can produce hydroxyl radicals. Arch Toxicol 72: 690-700, 1998.

OGNJANOVIĆ B, ŽIKIĆ RV, ŠTAJN A, SAIČIĆ ZS, KOSTIĆ MM, PETROVIĆ VM: The effects of selenium on the antioxidant defense system in the liver of rats exposed to cadmium. Physiol Res 44: 293-300, 1995.

OGNJANOVIĆ B, PAVLOVIĆ SZ, MALETIĆ SD, ŽIKIĆ RV, ŠTAJN A, RADOJIČIĆ RM, SAIČIĆ ZS, PETROVIĆ VM: Protective influence of vitamin E on antioxidant defense system in the blood of rats treated with cadmium. Physiol Res 52: 563-570, 2003.

OGNJANOVIĆ B, MARKOVIĆ SD, PAVLOVIĆ SZ, ŽIKIĆ RV, ŠTAJN A, SAIČIĆ ZS: Combined effects of coenzyme $\mathrm{Q}_{10}$ and vitamin $\mathrm{E}$ in cadmium induced alterations of antioxidant defense system in the rat heart. Environ Toxicol Pharmacol 22: 219-224, 2006.

OHKAWA H, OKISHI N, YOGI K: Assay for lipid peroxides in animal tissues by thiobarbituric acid reaction. Anal Biochem 95: 351-358, 1979.

OMAYE ST, TURNBULL JD, SAUBERLICH HE: Selected methods for the determination of ascorbic acid in animal cells, tissues and fluids. Methods Enzymol 62: 3-14, 1979.

PAVLOVIĆ SZ, OGNJANOVIĆ BI, ŠTAJN AŠ, ŽIKIĆ RV, SAIČIĆ ZS, PETROVIĆ VM: Antioxidant defense system in skeletal muscle of rats treated with cadmium. A possible protective role of coenzyme $\mathrm{Q}_{10}$. Jugoslav Med Biochem 20: 229-235, 2001.

PATRA RC, SWARUP D, SENAPATI SK: Effects of cadmium on lipid peroxides and superoxide dismutase in hepatic, renal and testicular tissue of rats. Vet Hum Toxicol 41: 65-67, 1999.

SARKAR S, YADOV P, BHATNAGAR D: Lipid peroxidative damage on cadmium exposure and alterations in antioxidant system in rat erythrocytes: A study with relation to time. BioMetals 11: 153-157, 1998.

SAITO Y, YOSHIDA Y, AKAZAWA T, TAKAHASHI K, NIKI E: Cell death caused by selenium deficiency and protective effect of antioxidants. J Biol Chem 278: 39428-39434, 2003.

SHAIKH ZA, VU TT, ZAMAN K: Oxidative stress as a mechanism of chronic cadmium-induced hepatotoxicity and renal toxicity and protection by antioxidants. Toxicol Appl Pharmacol 154: 256-263, 1999.

SHIRLEY RL, BEUNE WJ, MILLER EJ. Cadmium in biological materials and food. Anal Chem 21: 300-303, 1949.

SHUKLA GS, CHANDRA SV: Cadmium toxicity and bioantioxidants: status of vitamin E and ascorbic acid of selected organs in rat. J Appl Toxicol 9: 119-122, 1989.

STOHS SJ, BAGCHI D: Oxidative mechanisms in the toxicity of metal ions. Free Radic Biol Med 18: 321-336, 1995.

ŠTAJN A, ŽIKIĆ RV, OGNJANOVIĆ B, SAIČIĆ ZS, PAVLOVIĆ SZ, KOSTIĆ MM, PETROVIĆ VM: Effect of cadmium and selenium on the antioxidant defense system in rat kidneys. Comp Biochem Physiol 117C: 167$172,1997$.

TAMURA M, OSCHINO N, CHANCE B: Some characteristics of hydrogen and alkylhydro-peroxides metabolizing systems in cardiac tissue. J Biochem 92: 1019-1031, 1982.

TANDON SK, SINGH S, PRASAD S, KHANDEKAR K, DWIVEDI VK, CHATTERJEE M, MATHUR N: Reversal of cadmium induced oxidative stress by chelating agent, antioxidant or their combination in rat. Toxicol Lett 145: 211-217, 2003.

VILJOEN JA, TAPPEL LA: Interactions of selenium and cadmium with metallothionein-like and other cytosolic proteins of rat kidney and liver. J Inorg Biochem 34: 277-290, 1988.

WAISBERG M, JOSEPH P, HALE B, BEYERSMANN D: Molecular and cellular mechanisms of cadmium carcinogenesis: a review. Toxicology 192: 95-117, 2003.

WAHBA ZZ, COOGAN TR, RHODES SW, WAALKES MP: Protective effects of selenium on cadmium toxicity in rats - Role of altered toxicokinetics and metallothionein. J Toxicol Environ Health 38: 171-182, 1993.

WU Q, HUANG K: Effect of long-term Se deficiency on the antioxidant capacities of rat vascular tissue. Biol Trace Elem Res 98: 73-84, 2004. 
ŽIKIĆ RV, ŠTAJN AŠ, OGNJANOVIĆ BI, PAVLOVIĆ SZ, KOSTIĆ MM: The effect of cadmium and selenium on the ascorbic acid and vitamin E contents in the plasma and liver of young and adult rats. Coll Sci Pap Fac Sci Krag 17: 203-213, 1995.

ŽIKIĆ R, ŠTAJN A, SAIČIĆ Z, SPASIĆ M, ZIEMNICKI K, PETROVIĆ V: The activities of superoxid dismutase, catalase and ascorbic acid content in the liver of goldfish (Carassius auratus gibelio Bloch.) exposed to cadmium. Physiol Res 45: 479-481, 1996.

ŽIKIĆ RV, ŠTAJN AŠ, OGNJANOVIĆ BI, SAIČIĆ ZS, KOSTIĆ MM, PAVLOVIĆ SZ, PETROVIĆ VM: The effect of cadmium and selenium on the antioxidant enzyme activities in rat heart. J Environ Pathol Toxicol Oncol 17: 259-264, 1998. 